\title{
Beggar Thy Neighbor
}




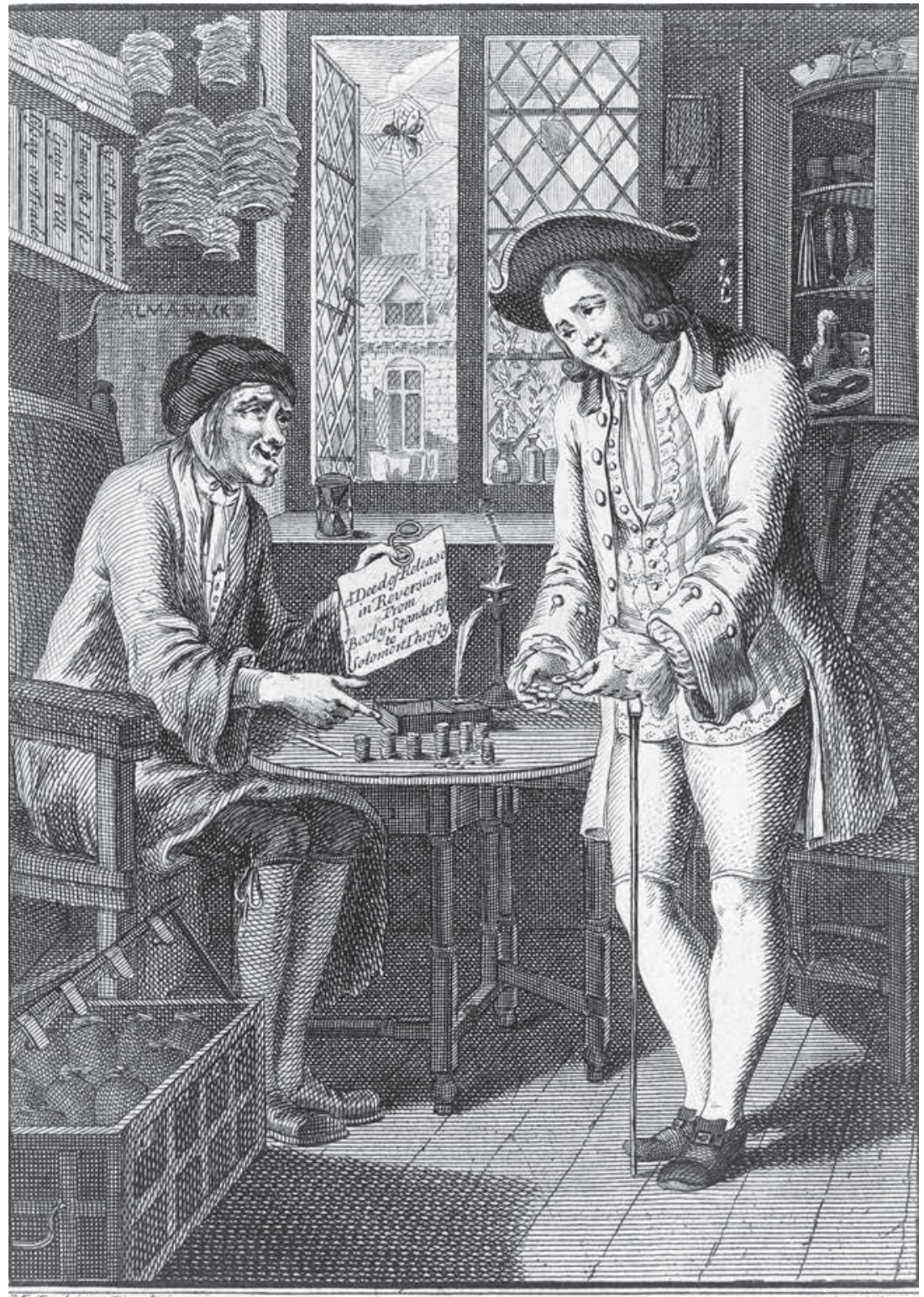

Boitand Joudp

The Prodigals Nurse; or Modern Heir .

Irom faronts \&f from triends, set fice? TY. Niws, theqles rerhe applies, -

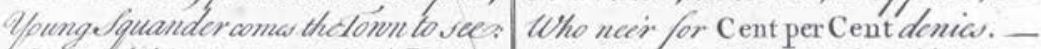

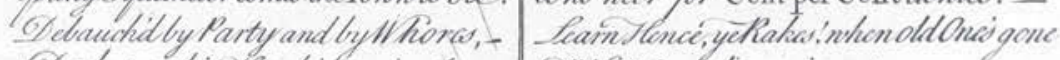

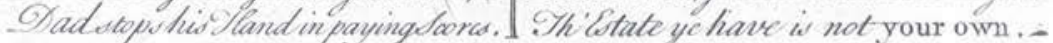

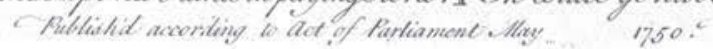




\section{Beggar Thy Neighbor}

A History of Usury and Debt

\section{Charles R. Geisst}

\section{$\overline{\text { PENN }}$}

UNIVERSITY OF PENNSYLVANIA PRESS

Philadelphia 
Copyright @ 2013 University of Pennsylvania Press

All rights reserved. Except for brief quotations used for purposes of review or scholarly citation, none of this book may be reproduced in any form by any means without written permission from the publisher.

Published by

University of Pennsylvania Press

Philadelphia, Pennsylvania 19104-4112

www.upenn.edu/pennpress

Printed in the United States of America on acid-free paper

$\begin{array}{llllllllll}10 & 9 & 8 & 7 & 6 & 5 & 4 & 3 & 2 & 1\end{array}$

Library of Congress Cataloging-in-Publication Data

Geisst, Charles R.

Beggar thy neighbor : a history of usury and debt / Charles R. Geisst. 1 st ed.

p. $\mathrm{cm}$.

Includes bibliographical references and index.

ISBN 978-0-8122-4462-5 (hardcover : alk. paper)

1. Usury-History. 2. Usury-Religious aspects-History.

3. Usury laws-History. 4. Debt-History. I. Title.

HB551.G45 2013

$332.8^{\prime} 309-\mathrm{dc} 23$

2012022355

Frontispiece: Louis-Philippe Boitard, The Prodigals Nurse; or Modern Heir (1750). Engraving. Library of Congress Prints and Photographs Division, Washington, D.C. 20540 USA. The lines beneath the image read: "From Parents \& from friends set free, / Young Squander comes the Town to see; / Debauch'd by Party and by Whores, / Dad stops his Hand in paying Scores / To Nurse, the Us'rer, he applies, / Who nee'r for Cent per Cent denies. / Learn Hence, ye Rakes! when old One's gone / Th' Estate ye have is not your own." 